\title{
Academia da Melhor Idade e Pinda Cidadã: promovendo saúde $e$ cidadania em Pindamonhangaba
}

Mariana Prado Freire

Secretaria de Saúde e Promoção Social de Pindamonhangaba.

Endereço: Rua Major José dos Santos Moreira, 570, andar superior, Centro, CEP 12400-ooo, Pindamonhangaba, SP, Brasil.

E-mail: saúde@pindamonhangaba.sp.gov.br

O município de Pindamonhangaba iniciou, em 2007, a instalação de "Academias da Melhor Idade" (conjunto de aparelhos para a realização de atividades físicas projetadas para a melhor idade) e a realização do evento Pinda Cidadã (ação intersetorial, itinerante e regionalizada, com procedimentos, orientações e 
atividades voltadas à prevenção e promoção da saúde), como parte integrante da política de promoção de saúde e cidadania, desenvolvida pela Secretaria de Saúde e Promoção Social. Considerando que a mudança no modelo de assistência à saúde é uma exigência contemporânea na esfera da Saúde Pública, cuidar da prevenção às doenças é um desafio constante para os gestores, trabalhadores e colaboradores da área da Saúde. Pindamonhangaba, município do Vale do Paraíba, com 135 mil habitantes, vem investindo nessa fórmula e observa resultados animadores, com repercussão popular imediata após a implantação e expansão dessas ações. 